\title{
Numerical study of the Martelange mine to be used as underground reservoir for constructing an Underground Pumped Storage Hydropower plant
}

\author{
Estanislao Pujades ${ }^{1}$, Philippe Orban ${ }^{2}$, Pierre Archambeau $^{3}$, Sebastien Erpicum ${ }^{3}$, and Alain Dassargues ${ }^{2}$ \\ ${ }^{1}$ Department of Computational Hydrosystems, UFZ - Helmholtz Centre for Environmental Research, \\ Permoserstr. 15, 04318 Leipzig, Germany \\ ${ }^{2}$ Hydrogeology and Environmental Geology, Geo3, Dpt ArGEnCo, Aquapole, University of Liege, 4000 Liege, Belgium \\ ${ }^{3}$ Hydraulics in Environmental and Civil Engineering (HECE), Dpt ArGEnCo, Aquapole, \\ University of Liege, 4000 Liege, Belgium
}

Correspondence: Estanislao Pujades (estanislao.pujades@gmail.com, estanislao.pujades-garnes@ufz.de)

Received: 31 May 2018 - Accepted: 2 July 2018 - Published: 27 July 2018

\begin{abstract}
Underground Pumped Storage Hydropower (UPSH) using abandoned mines has been considered as a potential high capacity Energy Storage Systems. In UPSH plants, the excess of electricity is stored in the form of potential energy by pumping water from an underground reservoir (abandoned mine in this paper) to a surface reservoir, while electricity is produced (when the demand increases) discharging water from the surface into the underground reservoir. The main concerns may arise from the water exchanges occurring between the underground reservoir and the surrounding medium, which are relevant in terms of environmental impact and UPSH efficiency. Although the role of the water exchanges has been previously addressed, most studies are based on synthetic models. This work focuses on a real abandoned slate mine located in Martelange (Belgium). The effects of different rehabilitation works to prepare the mine as an underground reservoir are assessed in terms of groundwater exchanges and their associated consequences.
\end{abstract}

\section{Introduction}

Energy Storage Systems are needed to increase the efficiency of current and future renewable energies, whose production is not always adapted to the demand. In this context, underground pumped storage hydropower (UPSH) using abandoned mines is a potential alternative (Martin and Barnes, 2007; Pickard, 2012; Pummer and Schüttrumpf, 2018), es- pecially in flat regions where conventional pumped storage hydropower plants cannot be constructed because they require steep topography. UPSH plants consist of two reservoirs, one is underground while the other is located at the surface (Barnes and Levine, 2011). Although the underground reservoir can be drilled or excavated, the option considered in this work consists in using existing cavities from abandoned mines. This option presents some benefits, e.g., it may contribute to the economic development after cessation of mining activities and as industrial site rehabilitation.

During low demand energy periods, UPSH plants store the excess of electricity under the form of potential energy by pumping water from the mine to the surface reservoir, whilst the electricity is generated during high demand energy periods by discharging water from the surface into the underground reservoir through turbines. UPSH possibilities have been investigated in different parts of the world: The Netherlands (Min, 1984), Singapore (Wong, 1996), USA (Allen et al., 1984; Severson, 2011), Germany (Beck and Schmidt, 2011; Zillman and Perau, 2015; Alvarado et al., 2016), Belgium (Bodeux et al., 2016; Poulain et al., 2018), Spain (Menéndez et al., 2017), South Africa (Winde and Stoch, 2010a, b; Khan and Davidson, 2016; Winde et al., 2017), Finland and Australia (Academy of Science of South Africa, 2018). However, there are no bibliographical evidences of constructed UPSH plants. Some critical issues must be addressed and solved before constructing them.

The main concern with respect to the use of abandoned mines as underground reservoir is that mine walls are rarely 
waterproofed, and consequently, flow and hydrochemical related issues may arise. For example, hydrochemical changes may influence the efficiency of UPSH plants as well as the impact on the environment when sulphide minerals $(\mathrm{pH}$ decrease and corrosion) or carbonate minerals ( $\mathrm{pH}$ increase and incrustations) are present in the surrounding medium (Winde and Stoch, 2010a, b; Pujades et al., 2017, 2018). Although hydrochemical aspects are important, this manuscript is only focused on flow-related issues that may modify the natural groundwater flow and affect the efficiency of the plant. Efficiency is affected by groundwater seepage when groundwater head in natural conditions is above the top of the cavity. During periods of pumping and storage in the surface reservoir, groundwater seepage fills the cavity and limits the volume of discharged water for producing electricity (Bodeux et al., 2017). As a result, much more energy is used for pumping than that produced during the discharging phase. Flow related problems produced by the interaction between UPSH and surrounding groundwater have been previously quantified by means of numerical models by some authors such as Poulain et al. (2016, 2018) or Bodeux et al. (2017). Pujades et al. (2016) described the main possible impacts produced on groundwater flow. They consist in continuous piezometric head oscillations produced by the pumpings and discharges. After an initial piezometric head drop and a progressive recovery, the piezometric head tends to oscillate around the position of the piezometric head in natural conditions. These previous works present some lacks that are addressed in this study. For example, previous works consider that the piezometric head is in natural conditions when the activity of the plant starts, therefore, that the underground reservoir is initially filled. This assumption may not be realistic if rehabilitation tasks are undertaken to readapt the mine to be used for UPSH. These tasks would require draining the mine. In addition, although some previous works are focused on real cases (Beck and Schmidt, 2011; Winde et al., 2017), none of them, with the exception of Bodeux et al. (2017), quantify numerically the interaction between groundwater and a UPSH plant based on real data from a deep abandoned mine. Finally, previous studies do not investigate the influence of the mine architecture on the water exchanges and their consequences.

This work is focused in a real deep abandoned mine (Martelange mine) and investigates how the connectivity between the mine chambers (i.e., the architecture of the mine) influences water exchanges and their associated impacts. It is assumed that this connectivity could be modified during the rehabilitation phase by drilling galleries between the mine chambers. Given that rehabilitation tasks would be required, this work also considers that the abandoned mine is totally drained at the beginning of the operational phase. The main objective of this work is to evaluate how the architecture of the mine influences the water exchanges and their associated consequences (environmental impacts and efficiency).

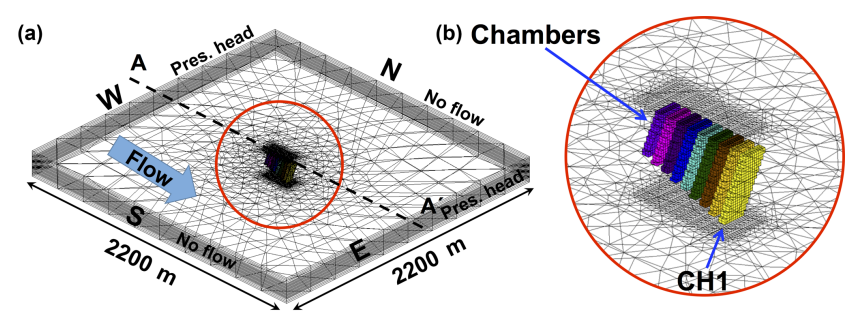

Figure 1. General view of the numerical model (a) and detailed view of the modelled chambers (b).

\section{Methods}

\subsection{Problem statement}

The Martelange mine is located in the South-East of Belgium (Ardennes region). This mine was exploited using the "room and pillar" mining technique and was abandoned in the 1980s. The remaining volume that could be used as underground reservoir, which is estimated in $400000 \mathrm{~m}^{3}$, consists in 9 underground adjacent chambers. The top of the chambers is located $30 \mathrm{~m}$ below the surface while their bottoms are located at different depths. The size of the chambers is 50 by $20 \mathrm{~m}$ and their height ranges from 110 to $70 \mathrm{~m}$. The height of the chambers decreases progressively from E to W (Fig. 1). Currently, the chambers are flooded. This means that the groundwater natural head is above the top cavity elevation. It is considered that an initial dewatering would be needed for rehabilitation works. During the rehabilitation period, galleries could be drilled increasing the connectivity between chambers. In addition, the chambers could be connected with the surface through chimneys for facilitating the air exchange with the atmosphere and thus minimizing the internal pressure variations when water is discharged/pumped.

\subsection{Numerical modelling}

\subsubsection{Numerical model characteristics}

The finite element numerical code SUFT3D (Brouyère et al., 2009; Wildemeersch et al., 2010) is used to model the underground reservoir and its interaction with the porous medium. This code uses the Control Volume Finite Element (CVFE) method to solve the groundwater flow equation based on the mixed formulation of Richard's equation proposed by Celia et al. (1990). Figure 1 displays a view of the model discretization. The mesh is made up of prismatic 3-D elements and is divided vertically into 29 layers. The horizontal size of the elements decreases towards the underground reservoir (from $150 \mathrm{~m}$ near the boundaries to $5 \mathrm{~m}$ in the center of the domain). Each of the nine chambers is modelled as a linear reservoir and is discretized as single mixing cell. The velocity inside the mixing cells is neglected. The hydraulic parameters cho- 


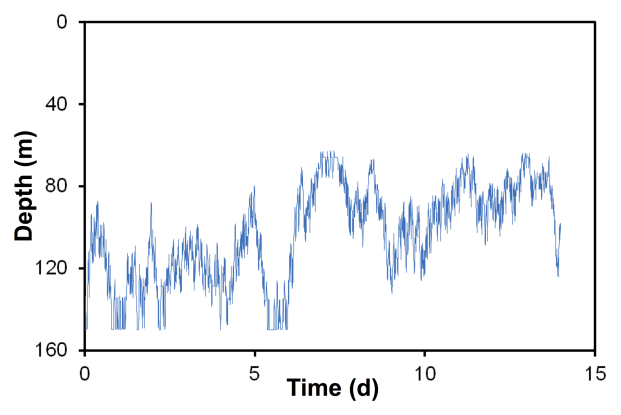

Figure 2. Prescribed head evolution inside the mine chamber 1 (CH1).

sen are typical of slate mines and are representative of the soil properties at the considered mine site (Bear and Cheng, 2010; DGO3, 2008). The hydraulic conductivity is $10^{-7} \mathrm{~m} \mathrm{~s}^{-1}$, the specific storage coefficient is $10^{-4} \mathrm{~m}^{-1}$, the saturated water content is 0.05 and the residual water content is 0.01 .

\subsubsection{Boundary conditions}

Piezometric head is prescribed on the model boundaries at a depth of 29 and $30 \mathrm{~m}$ on the upgradient (W) and downgradient (E) sides, respectively. Thus, considering the orientation of Fig. 1, groundwater flows from $\mathrm{W}$ to $\mathrm{E}$ and the hydraulic gradient is $4.6 \times 10^{-4}$. No-flow boundary conditions are adopted at the $\mathrm{N}$ and $\mathrm{S}$ boundaries. An internal dynamic Fourier boundary condition (BC), which is a head-dependent BC (Brouyère et al., 2009), between the chambers (i.e., underground reservoir) and the surrounding porous medium is used to simulate the groundwater exchanges. The hydraulic head evolution is prescribed inside each chamber. The head evolution inside the chambers is computed using a distributed hydraulic model taking into account air movement and assuming a random evolution of the electrical demand (Erpicum et al., 2017). It is assumed that water is only pumped from and discharged into the largest chamber ( $\mathrm{CH} 1$ in Fig. 1). Figure 2 shows, as an example, the prescribed head evolution at the chamber $\mathrm{CH} 1$ for one of the modeled scenarios (Sce1).

\subsubsection{Initial conditions}

Rehabilitation works would probably be needed for adapting the abandoned mine to be used as an underground reservoir. These tasks would require dewater the mine for working under dry and safe conditions. The piezometric head during this period must be located, at least, at the bottom of each chamber. Thus, the initial conditions are computed by simulating a steady state model in which the head is prescribed at the bottom of the chambers. A steady condition is considered because the dewatering is expected to be long enough. The rest of the boundary conditions adopted for this steady state simulation are the same as explained previously. Figure 3 shows the pressure head distribution computed and used further as

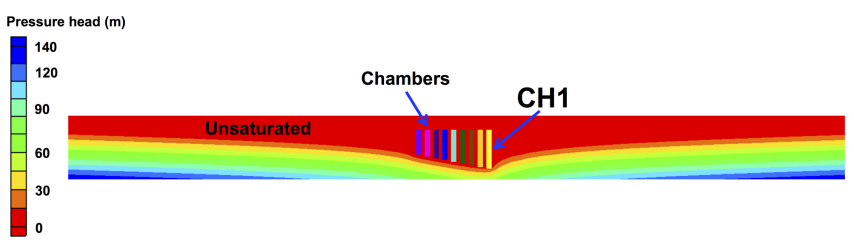

Figure 3. Computed pressure head distribution used as initial condition for the transient state simulations.

initial conditions. Results are shown for the section A-A' in Fig. 1 showing that the water level is indeed below the bottom of all chambers.

\subsubsection{Considered Scenarios}

Three scenarios (Sce1, Sce2 and Sce3) are chosen according to the actual architecture of the mine, which could be adapted during the rehabilitation phase. Sce1 considers that two galleries connect the chambers. The galleries are located at the top and bottom of the chambers. Sce 2 considers ten galleries at different heights (equally distributed) connecting the chambers. Finally, Sce3 considers also two galleries for connecting the chambers, but in this case, chambers are totally isolated from the surface and consequently, no air exchange is possible with the atmosphere, i.e. the existing air volume in the cavities will be compressed during the discharge period (when the chambers are filled by water) and may limit the volume of stored water in the chambers.

\section{Results}

\subsection{Groundwater flow impact}

The piezometric head is computed at the downgradient and lateral sides of the mine. The observation points are located at $55 \mathrm{~m}$ (downgradient) and $15 \mathrm{~m}$ (laterally) from the mine. Figure 4 shows the piezometric head evolution in both observation points for the three considered scenarios. The piezometric head increases with time because an initial dewatering was considered and due to the influence of the prescribed piezometric head BC's. The recovery would stop once the piezometric head reaches an elevation similar to natural conditions. Oscillations are not observed because the hydraulic conductivity of the medium is low. In addition, the continuous recovery mitigates them. Piezometric head recovers faster when 10 galleries are connecting the chambers (Sce2). It means that under this scenario, less groundwater will further flow in the mine. Differences between scenarios Sce1 and Sce 3 are small. Piezometric head in Sce1 is slightly higher than that observed in Sce3 at the downgradient observation point (Fig. 4 left), whilst the opposite behaviour is observed in the lateral observation point (Fig. 4 right). In any case, differences between Sce1 and Sce3 are negligible, which indicates that the isolation of the chambers with re- 

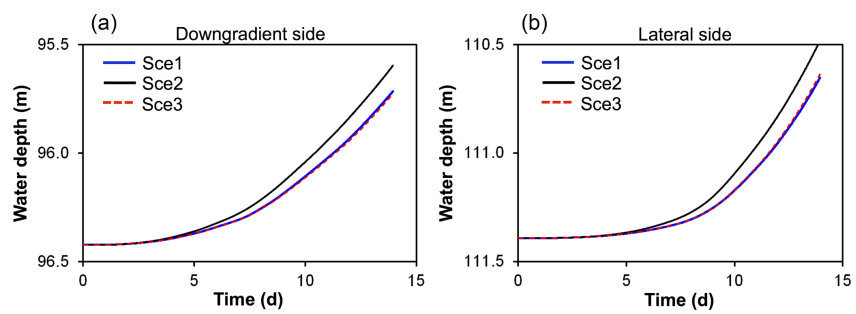

Figure 4. Piezometric head evolution at two observation points. Piezometric head is computed at the downgradient (a) and lateral (b) sides of the Martelange mine.
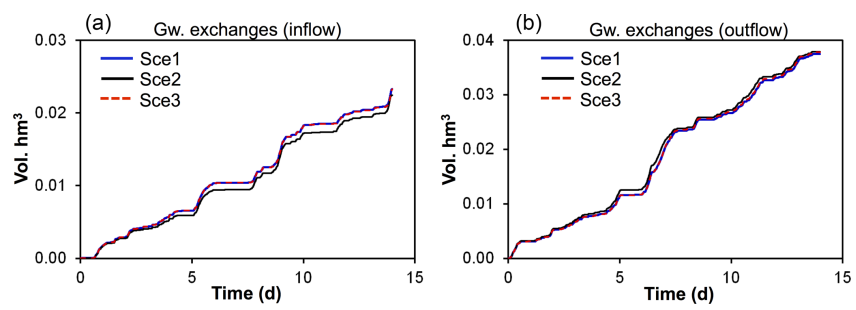

Figure 5. Volume of water that flows in (a) and flows out (b) the mine during the simulated period.

spect to the surface has no influence on these piezometric heads.

\subsection{Water exchanges}

Figure 5 displays the total volume of water that flows in (Fig. 5 on the left) and flows out (Fig. 5 on the right) of the mine during the simulated period. Volume of water is computed for each time step by adding the results of all chambers. As deduced from the piezometric head evolution, less groundwater flows inside the mine and more water flows out when the connectivity between chambers is increased (Sce2). The water head distribution inside the mine is more homogeneous when the connectivity of the mine chambers is increased. As a result, the hydraulic gradient between the mine and the surrounding medium evolves more homogeneously than in the other scenarios. Conversely, when connectivity is low (Sce1 and Sce3), the hydraulic head changes faster inside the chamber in which water is pumped or discharged. As a result, the hydraulic gradient between the mine and the surrounding medium changes faster around this chamber than around the other ones. Globally, more groundwater enters into the mine and less water flows out when the connectivity between chambers is reduced.

\section{Discussion and conclusions}

This work investigates the influence of the actual mine geometry on the water exchanges when old mines are used as underground reservoirs for UPSH. The results show that the connectivity between the different mine cavities (chambers) affects the water exchanges between the mine and the surrounding medium. This connectivity may thus influence the environmental impact and the efficiency of the plant. If the connectivity between mine cavities is increased, less groundwater enters into the mine, which may be positive in terms of efficiency. The volume of cavity filled by water exchanges during the period in which water is pumped and stored in the surface reservoir is decreased as the difference between the volumes of pumped and discharged water. Contrary, more water flows out the mine, which may influence environmental impacts (Pujades et al., 2016). On the one hand, the piezometric head recovers faster after the previous dewatering and it needs less time to reach its natural elevation. On the other hand, if any pollutant was accidentally discharged in the reservoirs, it would reach faster the underground environment.

If the mine is totally isolated with respect to the surface, the pressure inside the chambers will increase as they are filled by water, but it does not influence the water exchanges between the underground reservoir and the surrounding medium.

Old mine rehabilitation tasks should be undertaken to adapt abandoned mines as underground reservoirs for UPSH. A special attention must be given to the effects of increasing the connectivity between the mine chambers or cavities. For that purpose, galleries homogeneously distributed between them could be drilled.

Data availability. Data containing the numerical results presented in this article are openly available in Open Science Framework at https://doi.org/10.17605/OSF.IO/EFWZY (Pujades, 2018).

Competing interests. The authors declare that they have no conflict of interest.

Special issue statement. This article is part of the special issue "European Geosciences Union General Assembly 2018, EGU Division Energy, Resources \& Environment (ERE)". It is a result of the EGU General Assembly 2018, Vienna, Austria, 8-13 April 2018.

Acknowledgements. Estanislao Pujades gratefully acknowledges the financial support from the University of Liège and the EU through the Marie Curie BeIPD-COFUND postdoctoral fellowship programme (2014-2016 "Fellows from FP7-MSCA-COFUND, 600405"). This research was supported by the Public Service of Wallonia - Department of Energy and Sustainable Building through the Smartwater project.

The article processing charges for this open-access publication were covered by a Research Centre of the Helmholtz Association. 
Edited by: Luke Griffiths

Reviewed by: Christopher Juhlin and Friederike Kaiser

\section{References}

Academy of Science of South Africa: Science Business Society Dialogue Conference: Strengthening the Science Business Society Dialogue in the SADC Region, Johannesburg, South Africa, 2830 November 2017, http://research.assaf.org.za/handle/20.500. 11911/99?show=full, last access: 24 July 2018.

Allen, R. D., Doherty, T. J., and Kannberg, L. D.: Underground pumped hydroelectric storage, NASA STI/Recon Technical Report N, 85, 1984.

Alvarado, R., Niemann, A., and Wortberg, T.: Underground Pumped-Storage Hydroelectricity using existing Coal Mining Infrastructure, in: E-proceedings of the 36th IAHR World Congress, The Hague, the Netherlands, 28 June-3 July 2015, 2016.

Barnes, F. S. and Levine, J. G. (Eds.): Large Energy Storage Systems Handbook, CRC Press, USA, 2011.

Bear, J. and Cheng, A. H.-D.: Modeling Groundwater Flow and Contaminant Transport, Springer Science and Business Media, 2010.

Beck, H. P. and Schmidt, M. Windenergiespeicherung durch Nachnutzung stillgelegter Bergwerke, Clausthal-Zellerfeld, Univ.Bibliothek Clausthal, 2011.

Bodeux, S., Pujades, E., Orban, P., Brouyère, S., and Dassargues, A.: How groundwater interactions can influence UPSH (Underground Pumping Storage Hydroelectricity) operations, in: Sustainable Hydraulics in the Era of Global Change, CRC Press, London, 973-973, 2016.

Bodeux, S., Pujades, E., Orban, P., Brouyère, S., and Dassargues, A.: Interactions between groundwater and the cavity of an old slate mine used as lower reservoir of an UPSH (Underground Pumped Storage Hydroelectricity): A modelling approach, Eng. Geol., 217, 71-80, https://doi.org/10.1016/j.enggeo.2016.12.007, 2017.

Brouyère, S., Orban, P., Wildemeersch, S., Couturier, J., Gardin, N., and Dassargues, A.: The hybrid finite element mixing cell method: a new flexible method for modelling mine ground water problems, Mine Water Environ., 28, 102-114, https://doi.org/10.1007/s10230-009-0069-5, 2009.

Celia, M. A., Bouloutas, E. T., and Zarba, R. L.: A general mass conservative numerical solution for the unsaturated flow equation, Water Resour. Res., 26, 1483-1496, 1990.

DGO3: Code wallon de bonnes pratiques - Gestion des sols - Guide de référence pour l'étude de risque, 2008.

Erpicum, S., Archambeau, P., Dewals, B., and Pirotton, M.: Underground pumped hydroelectric energy storage in Wallonia (Belgium) using old mines - Hydraulic modelling of the reservoirs, in: Proc. of the 37th IAHR World Congress, 13-18 August 2017, Kuala Lumpur, Malaysia, 2017.

Khan, S. Y. and Davidson, I. E.: Underground Pumped Hydroelectric Energy Storage in South Africa using Aquifers and Existing Infrastructure, in: NEIS Conference 2016, Springer Vieweg, Wiesbaden, 119-122, 2017.
Martin, G. D. and Barnes, F. S.: Aquifer underground pumped hydroelectric energy storage, in: Masters Abstracts International, 46, 3, 2007.

Menéndez, J., Loredo, J., Fernandez, J. M., and Galdo, M.: Underground pumped-storage hydro power plants with mine water in abandoned coal mines in northern Spain, in: Mine Water \& Circular Economy, edited by: Wolkersdorfer, C., Sartz, L., Sillanpää, M., and Häkkinen, A., 1, 6-14, Lappeenranta, Lappeenranta University of Technology, Finland, 2017.

Min, A. P. N.: Ondergrondse Pomp Accumulatie Centrale: Effectiviteitsverbetering d.m.v. verschillende pompturbinevermogens, MS thesis, Delft University of Technology, the Netherlands, 147 pp., 1984.

Pickard, W. F.: The history, present state, and future prospects of underground pumped hydro for massive energy storage, in: Proceedings IEEE, 100, 473-483, https://doi.org/10.1109/JPROC.2011.2126030, 2012.

Poulain, A., Goderniaux, P., and de Dreuzy, J. R.: Study of groundwater-quarry interactions in the context of energy storage systems, EGU General Assembly, Vienna, Austria, 17-22 April, EPSC2016-9055, 2016.

Poulain, A., De Dreuzy, J. R., and Goderniaux, P.: Pump Hydro Energy Storage systems (PHES) in groundwater flooded quarries, J. Hydrol., 559, 1002-1012, 2018.

Pujades, E.: Numerical Data: Hydrochemical Changes in UPSH, Influence of Hydraulic Parameters, Open Science Framework, https://doi.org/10.17605/OSF.IO/EFWZY, 2018.

Pujades, E., Willems, T., Bodeux, S., Orban, P., and Dassargues, A.: Underground pumped storage hydroelectricity using abandoned works (deep mines or open pits) and the impact on groundwater flow, Hydrogeol. J., 24, 1531-1546, https://doi.org/10.1007/s10040-016-1413-z, 2016.

Pujades, E., Orban, P., Bodeux, S., Archambeau, P., Erpicum, S., and Dassargues, A.: Underground pumped storage hydropower plants using open pit mines: How do groundwater exchanges influence the efficiency?, Appl. Energ., 190, 135-146, https://doi.org/10.1016/j.apenergy.2016.12.093, 2017.

Pujades, E., Jurado, A., Orban, P., Ayora, C., Poulain, A., Goderniaux, P., Brouyère, S., and Dassargues, A.: Hydrochemical changes induced by underground pumped storage hydropower and their associated impacts, J. Hydrol., 563, 927-941, 2018.

Pummer, E. and Schüttrumpf, H.: Reflection Phenomena in Underground Pumped Storage Reservoirs, Water, 10, 504, https://doi.org/10.3390/w10040504, 2018.

Severson, M. J.: Preliminary Evaluation of Establishing an Underground Taconite Mine, to be Used Later as a Lower Reservoir in a Pumped Hydro Energy Storage Facility, on the Mesabi Iron Range, Minnesota, 2011.

Wildemeersch, S., Brouyère, S., Orban, P., Couturier, J., Dingelstadt, C., Veschkens, M., and Dassargues, A.: Application of the hybrid finite element mixing cell method to an abandoned coalfield in Belgium, J. Hydrol., 392, 188-200, 2010.

Winde, F. and Stoch, E. J.: Threats and opportunities for postclosure development in dolomitic gold mining areas of the West Rand and Far West Rand (South Africa)-a hydraulic view Part 1: Mining legacy and future threats, Water SA, 36, 69-74, https://doi.org/10.4314/wsa.v36i1.50908, 2010a.

Winde, F. and Stoch, E. J.: Threats and opportunities for post-closure development in dolomitic gold-mining areas of 
the West Rand and Far West Rand (South Africa)-a hydraulic view Part 2: Opportunities, Water SA, 36, 75-82, https://doi.org/10.4314/wsa.v36i1.50909, 2010b.

Winde, F., Kaiser, F., and Erasmus, E.: Exploring the use of deep level gold mines in South Africa for underground pumped hydroelectric energy storage schemes, Renew. Sustain. Energ. Rev., 78, 668-682, 2017.

Wong, I. H.: An underground pumped storage scheme in the Bukit Timah Granite of Singapore, Tunn. Undergr. Sp. Tech., 11, 485489, https://doi.org/10.1016/S0886-7798(96)00035-1, 1996.
Zillmann, A. and Perau, E.: A conceptual analysis for an underground pumped storage plant in rock mass of the Ruhr Region, in: Proceedings of the XVI, European Conference on Soil Mechanics and Geotechnical Engineering (ECSMGE), Edinburgh, Scotland, 13-17 September 2015, ICE Publishing, 3789-3794, https://www.icevirtuallibrary.com/doi/abs/10.1680/ ecsmge.60678.vol7.597 (last access: 24 July 2018), 2015. 